\title{
A future for Palawan's forests?
}

\author{
Rupert Quinnell and Andrew Balmford
}

\begin{abstract}
Palawan is one of the last relatively undeveloped islands in the Philippines. It still has extensive forest cover, and is of considerable conservation importance. However, the remaining forests are disappearing fast in the face of rapid population growth and uncontrolled logging. The authors visited the island to carry out ecological fieldwork in 1984. Here they report on threats to the forests, and discuss the prospects for sustainable development on Palawan.
\end{abstract}

Palawan is the third largest of the Philippine islands (Figure 1). It is $440 \mathrm{~km}$ long and up to 40 $\mathrm{km}$ wide, and lies to the south-west of the main island group. A mountain chain runs along its centre, and natural vegetation is mostly lowland monsoon and semi-evergreen rain forest (sensu Whitmore, 1984). Palawan still has 59 per cent forest cover (Hunting Technical Services Ltd, 1985a) and its fisheries are the richest in the Philippines. In comparison with the rest of the archipelago, it has a low human population density ( 27 per sq $\mathrm{km}$ in 1983 compared with 170 per sq $\mathrm{km}$ nationwide) and is underdeveloped. Palawan is one of three priority areas for conservation in the Philippines (Hauge et al, 1986) and, in view of its underdevelopment, has probably the greatest potential for effective conservation of any of the major Philippine islands.

The importance of the island is enhanced by its varied geology, with very different forest types occurring on basaltic, ultrabasic and karst limestone bedrocks. Altogether 1672 species of higher plants are known (Anon., 1985). Annual rainfall is around $2000 \mathrm{~mm}$ on the east coast, although higher in the west, and there is a marked dry season from January to April, when less than 10 per cent of the rain falls. Palawan does not suffer from the typhoons that strike the northeastern edge of the Philippine archipelago.

Unlike the rest of the Philippines, Palawan is on the edge of the Sunda shelf, and the fauna and 30 flora are predominantly Bornean (i.e. Sundaic) in character. However, there is considerable overlap between Sundaic and Philippine biotas, making it of particular biogeographic interest (Diamond and Gilpin, 1983; Heaney, 1986). There is also a high degree of both specific and subspecific endemism. For instance, 11 of the 25 (44 per cent) indigenous non-flying mammal species are endemic to Palawan and its surrounding islands, as are 14 bird species.

At present all the Palawan endemic animals still survive in reasonable numbers, although the Palawan peacock pheasant Polyplectron emphanum ('vulnerable') and two swallowtails Graphium megaera and Atrophaneura atropos (both 'indeterminate') are listed in Red Data Books (King, 1981; Collins and Morris, 1985). In contrast, on the central Philippine island of Cebu, which has been almost completely deforested to make way for sugarcane plantations, all but one of 10 endemic bird species and subspecies were already extinct by the early 1960s (Rabor, 1962).

Palawan is important not only because of its endemic species, but also as a refuge for several species threatened over the rest of the archipelago, such as blue-naped parrot Tanygnathus lucionensis and, especially, the Philippine cockatoo Cacatua haematuropygia. The island may still harbour one of the last viable populations of the Philippine crocodile Crocodylus mindorensis.

Oryx Vol 22 No 1, January 1988 
However, Palawan is now entering a phase of rapid development. Large-scale immigration, partly as a result of guerrilla activity and the collapse of the sugarcane industry on other islands, contributes half of an annual population growth rate of 4.6 per cent (compared with 2.7 per cent nationwide; Hunting Technical Services Ltd, 1985b). The consequent threats to Palawan's forests are discussed below; their longterm effects can be seen throughout the rest of the country, where forest cover has been reduced to 36 per cent (Natural Resources Management Center, 1981). On the central islands (the Visayas) this figure is as low as 7 per cent. An appreciation of the importance of forest conservation, and its integration into future planning, is vital if Palawan is to experience sustainable economic development.

\section{Commercial logging}

Nearly all the island's forests are leased to logging operations. However, unlike those of Mindanao or Luzon, Palawan's forests are of low commercial value. Dipterocarps are poorly represented; there are, for example, none of the valuable Shorea spp. Because of this, large-scale logging has become economically viable only in

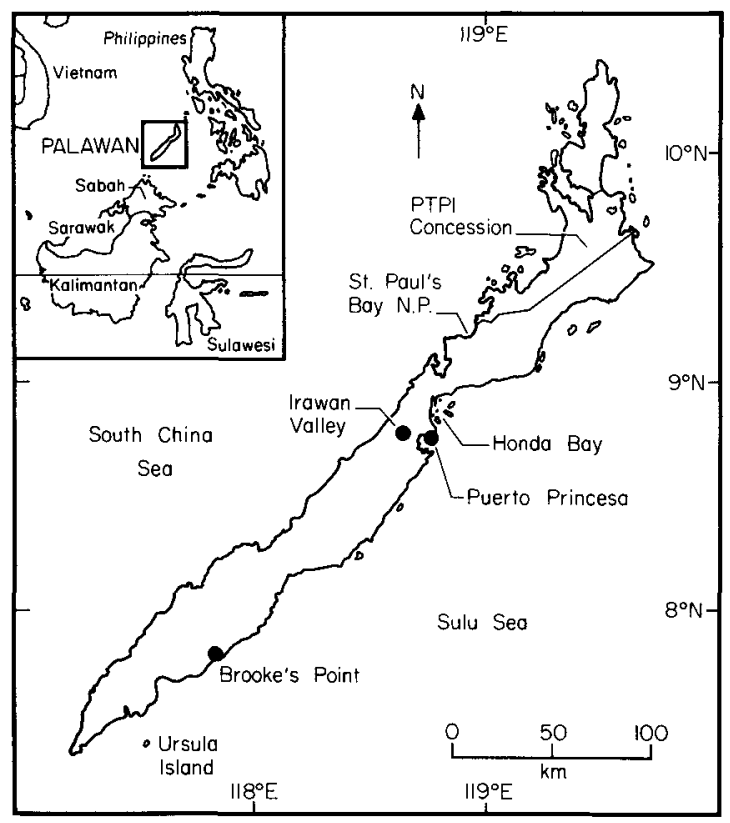

Figure 1. Map of Palawan, the Philippines. the last 20 years, after the depletion of more profitable forests elsewhere in the Philippines.

We visited the largest timber concession, belonging to Pagdanan Timber Products Inc. (PTPI). This covers 96,925 ha in the north-west of the island (Figure 1). PTPI cut 176,000 cubic $m$ of wood from 3000 ha of forest in 1982 . Half the timber PTPI cuts is turned into veneer and exported to Japan for plywood manufacture, 25 per cent is used locally, and 25 per cent is exported as logs to Japan-PTPI is exempt from the government ban on log exports (Hunting Technical Services Ltd, 1985c).

The Philippines has an established polycyclic silvicultural system, the 'selective logging system'. This allows a certain percentage of trees over specified girths to be cut, the forest then being left to regenerate. However, government girth limits are often ignored, and those mature trees left standing are frequently clumped, thus slowing regeneration. More importantly, many of the residual trees are greatly damaged by the extraction process. Even in well-controlled selective logging operations, extracting 10 per cent of the basal area, a further 55 per cent can be damaged during extraction (Burgess, 1971).

These problems are, of course, not unique to PTPI; they occur to a similar, or worse, degree all over the Philippines (Hyman, 1983; Bote and Calderon, 1984). Their solution depends on effective regulation, which is the responsibility of the Bureau of Forestry Development (BFD). However, staff shortages prevent BFD from fulfilling this role in remote areas, and with monthly salaries of only P800 ( $\$ 45,1984$ figures), officials may be subject to other influences.

The selective logging system assumes an interval between cuts of at least 35 years (Bote and Calderon, 1984), but with the problems detailed above this is in practice unattainable. For example, after only 10 years of extraction, Hunting Technical Services Ltd (pers. comm.) estimate that PTPI may have only $8-15$ years before the first cut of its entire concession is complete. Although some replanting, chiefly with Eucalyptus deglupta, is under way, this is done only half-heartedly, and is unlikely to be successful. Thus, PTPI's extraction policy precludes any possibility of sustainable harvesting. 
The other concessions on Palawan have yet to be extensively logged. However, experience suggests that, unless logging regulations can be enforced, the future for Palawan's commercially valuable forests and, ironically, for its logging industry, is gloomy.

\section{Kaingin}

'Kaingin' (Tagalog for slash-and-burn agriculture) is a major threat to the remaining forests of the Philippines. Large numbers of shifting slash-and-burn agriculturalists ('kaingineros') are the inevitable result of high population density, coupled with rule by a land-owning oligarchy. Although consistently underestimated in government censuses, there may be as many as 600,000 kainginero families in the Philippines (Duldulao, 1981).

Despite the low population density, kaingin has already had a devastating impact on Palawan. Lack of land rights in the lowlands forces immigrants to clear steep, forested hills, where the impact of kaingin, through erosion and loss of productive forest, is most severe. Between 1979 and 198413 per cent of the island's forests were destroyed by kaingin (Hunting Technical Services Ltd, 1985a). That rate of loss would destroy all forest cover on the island by the year 2009 . However, in view of the extraordinarily rapid population growth, and in the absence of land reform, the rate of forest loss through kaingin is likely to increase dramatically.

\section{Collecting and hunting}

Palawan is regarded as a major source of exotic birds in the USA (FORI-PIADP, 1983). Hunting, both for the pot and the bird trade, may have locally reduced the numbers of Palawan peacock pheasant around Puerto Princesa, the island's capital. Local prices in 1984 were P150 (\$8) per bird. At present, peacock pheasants are still reasonably common away from population centres, but their continued survival over most of the island would seem to depend on their ability to adapt to areas of logged forest and secondary

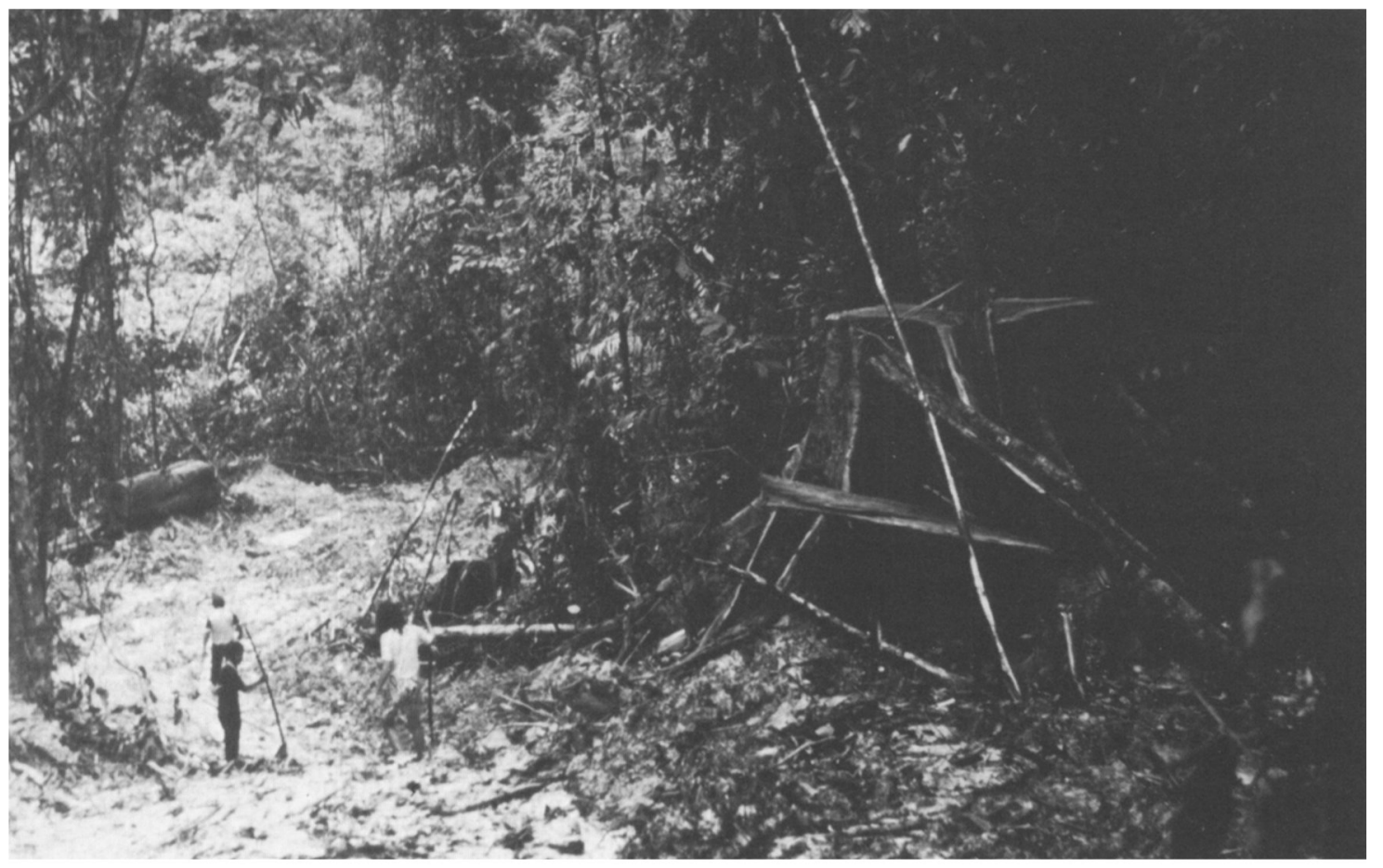




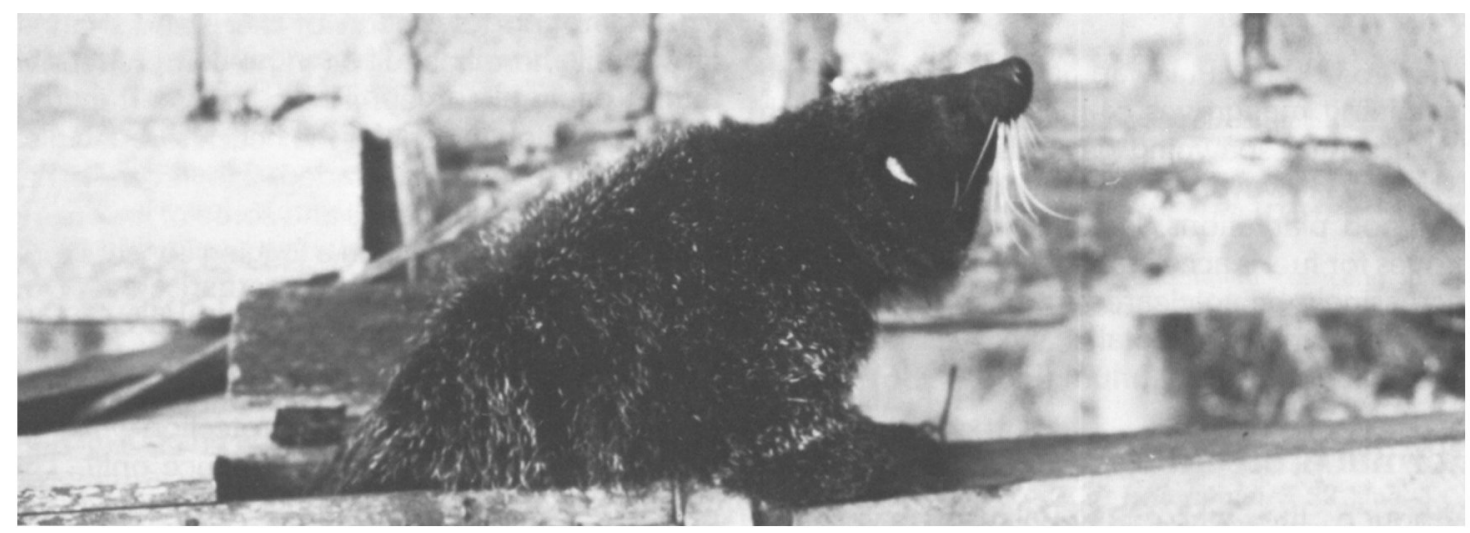

Binturong are threatened locally by the pet trade and by hunting ( $R$. Quinnell).

growth (King, 1981). Studies are currently under way on their habitat requirements and population densities.

Collecting of Philippine cockatoos and bluenaped parrots for the pet trade is widespread; we were offered a cockatoo for P80 (about \$5) during our stay. Other vertebrates potentially threatened by hunting include the binturong Arctictis binturong (hunted for meat and the pet trade) and the pangolin Manis javanicus (collected for its hide). Callous rampages by the military can present a less predictable localized threat. Shortly before our stay most of a large roosting colony of fruit-bats Pteropus vampyrus in Honda Bay was destroyed in a few days of 'target practice'.

Butterfly collecting, both for export and by Japanese tourists, is common but does not seem to be an immediate threat to species survival. For example, despite export of at least 2000 specimens of the endemic birdwing Troides plateni each year, this species is still common, even being seen in Puerto Princesa. The diversity of commercially valuable swallowtails on the island, and the fact that their foodplants can be readily cultivated, suggest that Palawan could become a major centre for the kind of butterfly farming that has been so successful in Papua New Guinea (Hutton, 1985; Collins and Morris, 1985; Harvey, 1986).

Collecting also threatens certain plant species. The conifer almaciga Agathis dammara has a Future for Palawan's forests? valuable resin, which is marketed as Manila copal. It is collected by tapping the bark and is an important local source of income on Palawan, especially for indigenous ethnic minority groups. In 1981 the average daily return on copal collecting was P18, about double the agricultural wage (Conelly, 1985). Although collecting is regulated by a system of licences and quotas, considerable overexploitation is now occurring. This is exacerbated by the overall reduction in forest area, and by the deliberate (though illegal) logging of almaciga in some areas. The remaining accessible trees now are either dead or produce inadequate amounts of resin, and collectors are having to travel further and further to find productive trees (Conelly, 1985). The long-term outlook for this species on Palawan seems very bleak (Anon., 1985; Quiniones, 1980).

\section{Mining}

Chromite, copper, iron, manganese, mercury and nickel are all found on Palawan, and oil has been found off the west coast. This abundant mineral wealth is, as yet, largely unexploited, although considerable local damage has already occurred. For instance, important stands of Agathis have been destroyed by open-cast mining around Brooke's Point and at the, now inactive, Philippine Chromite Mining Company mine in the Irawan valley. An eventual reversal in the current slump in world commodity prices is likely to result in increased exploitation leading to much more extensive forest loss. 


\section{Loss of mangroves}

With 46,000 ha, Palawan has 38 per cent of the remaining mangroves of the Philippines, which are essential spawning grounds for the island's fisheries. However, in the absence of commercial firewood plantations, local exploitation of mangroves for fuel is accelerating. Mangroves are also increasingly being cleared to make way for fishpond construction. Total mangrove loss is estimated at 350 ha per annum (Pido, 1986).

\section{Formal protection}

Although the whole of Palawan has been declared a 'Fauna and Flora Watershed Reserve' (Presidential Proclamation No. 2221), this protection is not enforced, and its implementation would anyway be impracticable. There is one national park, the 5390-ha St Paul's Bay Subterranean River National Park. This contains the longest underground river in the world and has spectacular karst limestone scenery, but its relative inaccessibility means that only the more adventurous visit it. Three vegetation types occur: lowland semi-evergreen forest, karst forest and beach forest (Anon., 1985), and these are likely

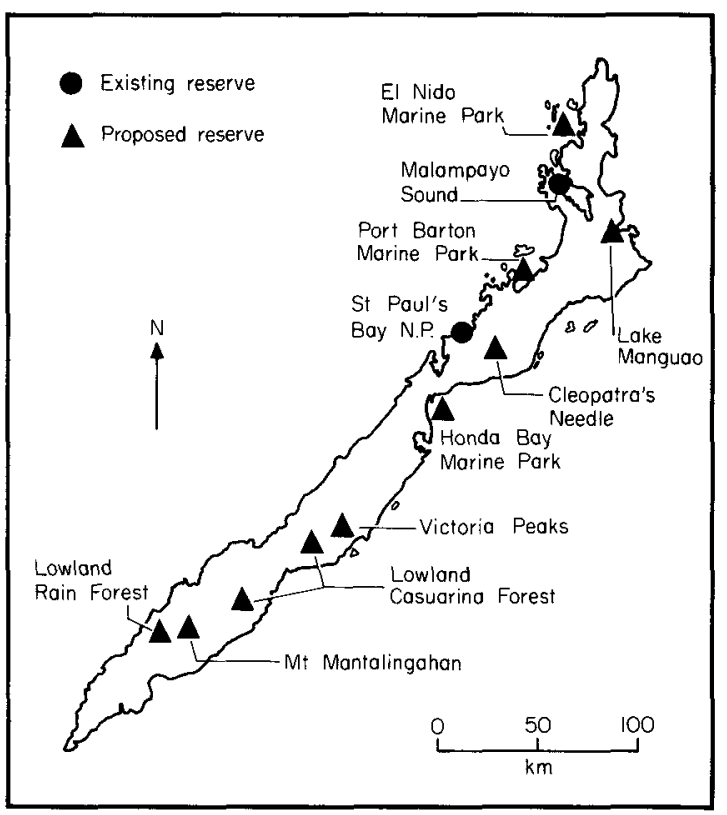

Figure 2. The network of protected areas proposed for Palawan (amended from Hunting Technical Services Ltd, 1985b). to hold a good selection of the island's fauna. However, there has still been no comprehensive faunal or floral survey. The park is currently in good condition except for the beach forest, which has been severely degraded. However, it has inappropriate boundaries and some of its forest is under threat, being within a logging concession.

The only other 'protected' areas in Palawan are Malampaya Sound, which was declared a marine sanctuary in 1973, and the Tabon Caves Park. The former has received little protection while the latter is of archaeological importance only. The creation of 10 additional parks and reserves has been proposed (Hunting Technical Services, 1985b; Anon., 1985), the locations of which are shown in Figure 2. Lake Manguao is the only lake on the island: it has endemic fish, as well as a rich avifauna in the surrounding forests. Mt Mantalingahan is the highest mountain (2084 m), with important montane forests. The Victoria Peaks area is the largest region of ultrabasic forest on Palawan, and contains the endemic tree genus Embolanthera. The other terrestrial reserves would all protect important areas of as yet undisturbed forest, while the marine parks would protect the most important coral reefs, and could have major tourist potential.

\section{Outlook}

Prospects for sustainable development in 'the last frontier of the Philippines' must realistically be considered bleak. Nevertheless, in the short term at least, there are grounds for some degree of optimism.

Some areas of the north, south, and west coast will continue to be buffered from rapid development by their sheer inaccessibility: the only major road on the island runs north-south along the east coast, and even this is unmetalled for most of its length. Malaria is a persistent hindrance to large-scale development programmes over much of the island. Reported cases are falling (from 15,380 per annum, 1976-1980) under the Malaria Control Programme (but DDT levels are now higher than anywhere else in the Philippines).

A detailed plan for the long-term, sustainable development of Palawan has recently been produced (Hunting Technical Services Ltd, 1985b). 
This suggests that Palawan could comfortably support its burgeoning population well into the 21 st century, and that the loss of upland forests can be halted. The agricultural potential of already cleared areas is still far from being fully realized. More intensive agriculture in the lowlands, combined with wide-ranging land reforms, incentive schemes and active direction of immigrants, could greatly reduce the impact of kaingin on the vulnerable upland forests. Furthermore, it calls for much more effective control of commercial logging activities, with the enforcement of silvicultural regulations.

The implementation of this important plan depends on the commitment the Government makes to effective development. However, such investment in the long-term future of the country will occur only in a climate of economic and political stability. Farmers and logging companies who believe that they have a future in a particular area have an obvious interest in seeking effective methods of ensuring renewable harvests. This contrasts with the 'bahala na'- 'it's not my problem' attitude to overexploitation, which is currently prevalent. Political and economic improvements over the rest of the Philippines would reduce the incentives for immigrating to Palawan, and thus increase the time available for development.

In the last years of the Marcos regime there was little chance of stability in the Philippines. We can only hope that the events of 1986 might change that. Palawan presents a unique challenge to the new Philippines' Government, and to the international conservation community.

\section{Acknowledgments}

Much of the information in this paper was gathered as part of Palawan Forest Research 1984, an undergraduate expedition to Palawan. We wish to thank all the sponsors and advisers of the expedition. The staff of the Palawan Integrated Area Development Project (PIADP), Stan Western and Dave Smith of Hunting Technical Services Ltd, Richard Lewis, Andrew Laurie, John Dransfield, Tim Whitmore and anonymous reviewers all made comments on earlier drafts of the paper. Mike Amphlett prepared the figures, and Hunting Technical Services Ltd kindly allowed the reproduction of Figure 2.

\section{References}

Anon. 1985. The Palawan Botanical Expedition Final Report. Hilleshog Forestry AB, Landskrona, Sweden.

Future for Palawan's forests?
Bote, P.P. and Calderon, A. 1984. Management scheme to improve the selective logging system. Canopy International, 10, 1-5.

Burgess, P.F. 1971. Effect of logging on hill dipterocarp forest. Malay Nat J., 24, 231-237.

Collins, N.M. and Morris, M.G. 1985. Threatened Swallowtail Butterflies of the World. The IUCNRed Data Book. IUCN, Gland.

Conelly, W.T. 1985. Copal and rattan collecting in the Philippines. Economic Botany, 39, 39-46.

Diamond, J.M. and Gilpin, M.E. 1983. Biogeographic umbilici and the origin of the Philippine avifauna. Oikos, 41, 301-341.

Duldulao, A. 1981. The implications of forest occupancy management on natural resources conservation. LikasYaman J. Nat. Resour. Manage. Forum, 3, 32 June.

FORI-PIADP. 1983. Survey and inventory of wildlife resources in Palawan, with particular emphasis on avian species. Vol. III. FORI-PIADP Project, Puerto Princesa.

Harvey, R. (Ed). 1986. The Cambridge Palawan Expedition 1985. Final Report. (unpublished).

Hauge, P., Terborgh, J., Winter, B. and Parkinson, J. 1986. Conservation priorities in the Philippine Archipelago. Forktail, 2, 83-91.

Heaney, L.R. 1986. Biogeography of mammals in S.E. Asia: estimates of colonization, extinction, and speciation. Biol. J. Linn. Soc., 28, 127-165.

Hunting Technical Services Ltd. 1985a. EMES Annual Report. Hunting Technical Services Ltd, Borehamwood, England.

Hunting Technical Services Ltd. 1985b. Strategic Environmental Plan for Mainland Palawan. Hunting Technical Services Ltd, Borehamwood, England.

Hunting Technical Services Ltd. 1985c. Logging Methods Review: Position Paper. Hunting Technical Services Ltd, Borehamwood, England.

Hutton, A.F. 1985. Butterfly farming in Papua New Guinea. Oryx, 19, 158-162.

Hyman, E.L. 1983. Forestry Administration and Policies in the Philippines. Environmental Management, 7 , $511-524$

King, W.B. 1981. Endangered birds of the world. The ICBP Red Data Book. IUCN, Morges.

Natural Resources Management Center (NRMC). 1981. Policies and Issues in Natural Resources. Quezon City, Ministry of Natural Resources, Government of the Philippines.

Pido, M. 1986. Palawan: on natural resources conservation. Canopy Intemational, 12, 4-5.

Quiniones, S.S. 1980. The diminishing Almacigas in Palawan: a report Canopy Intemational, 6, 13-14.

Rabor, D.S. 1962. The impact of deforestation on birds of Cebu, Philippines, with new records for that island. ICBP Bull., 7, 79-85.

Whitmore, T. 1984. Tropical rain forests of the Far East (2nd edition). Clarendon Press, Oxford.

Rupert Quinnell, Department of Zoology, South Parks Road, Oxford OX1 3PS, UK.

Andrew Balmford, Large Animal Research Group, Department of Zoology, Downing Street, Cambridge CB2 3EJ, $U K$. 